\title{
ECONOMIC ADVANCE, LIVING STANDARDS AND INEQUALITY IN OIL-PRODUCING FORMER SOVIET UNION COUNTRIES
}

This article covers the way oil export incomes influence economic development and inequality of income distribution. Possible types of inequality related to structural changes in the economies of oil-producing countries are identified. Dependency of different economies on oil and gas export has been analyzed based on the indicators suggested. A breakdown of oil-producing countries into four groups has been provided on the basis of average per capita incomes and volumes of oil extraction per capita. Peculiarities of resource-dependency of three major post-Soviet oil and gas exporters - Russia, Kazakhstan and Azerbaijan - have been analyzed. It has been demonstrated that dependency on resources modifies the structure of these countries' economies, which leads to income inequality based on employment via a mechanism of labor compensation changes in different sectors of the economy.

Oil-producing countries need the system policy on the effective use of income from the sale of energy to improve living standards and address emerging socio-economic challenges.

Keywords: income inequality, economic advance, resource curse, income distribution system 


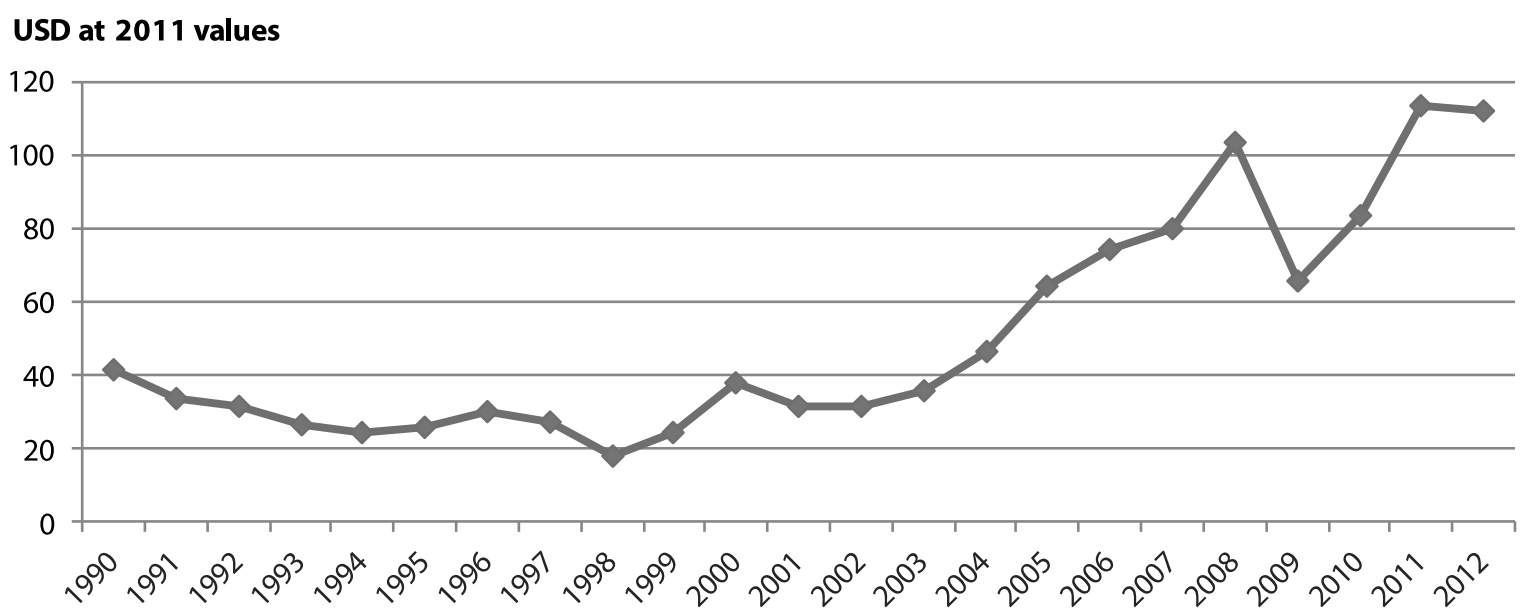

Pic. 1. Worldwide average oil prices throughout 1990-2012, US Dollars per 1 barrel, in comparison with the prices of 2011. Source: [20] Statistical Review of World Energy 2013. Available at: http://www.bp.com/en/global/corporate/about-bp/statistical-review-ofworld-energy-2013.html

In oil-producing countries living standards and level of inequality depend greatly on the system of distributing resources export incomes, which is defined by the government policy in the realm of social and economic issues. Increasing oil prices volatility during the last several years and their unpredictable upswing impact the income of export foreign currency revenue of oil-producing countries and their GDP growth.

Based on the dynamics of worldwide average oil prices in comparison with the prices of 2011 (Picture 1), during the last decade the price has grown from 31,94 USD in 2002 to 111,67 USD in 2012. Thus, many countries rich in oil deposits gained unplanned additional incomes. As a result, economic advance of such countries and their state budgetary expenditures became strongly dependent on export receipts.

However, researches show that not all oil-producing countries are capable to address social and economic challenges using additional oil resources export incomes, which confirms the theory of 'resource curse'. Such countries as Venezuela, Algeria, Nigeria Ecuador, etc. did not manage to take advantage of oil sales revenue in order to facilitate long-term economic advance and increase living standards.

This paradox, which was dubbed as 'resource curse' by the English economist R. Auty [2] stating the fact that living standards in oil-exporting countries in 1970-85s had decreased dramatically, has been discussed many times. For the first time, a conclusion on the slower advance of resources-rich countries was published in the cross-country research by J. Sachs and E. Warner [18]. According to them, there is an obvious negative correlation between the economic advance rate throughout 1970-90s and share of resources in export in 1970. It means that in resources-rich countries, they use these resources less effectively than other types of assets. Syrlybaeva B. [23] has note 'there is not a single country possessing considerable oil deposits that limits oil export significantly. On the contrary, those countries whose deposits are relatively small demonstrate disproportionately high share of oil export'.

$\mathrm{X}$. Sala-i-Martin has reviewed 2 million cross-country regression specifications for economic advance rates with different combinations of 62 variables and determined that there is a strong connection between natural resources abundance and economic advance [19]. A. Gelb [9] and M. Corden [6] have proven that a shortterm economic splash based on raw material resources export leads to institutions depreciation and growth rate reduction.

At the same time at the beginning of this century some economists have challenged the concept of 'resource curse' and reasoned economic policy problems in resource-dependent countries by an inability to effectively administer such revenues, not by resources availability. According to K. Brunnshweiller [4], many economically developed countries started their ways being sufficient in resources. As it was stated by T. Gylfason [11] and J. Hartwick [12], deficient institutions did not secure their footing in such countries and did not discourage long-term economic advance. S. Guriev and K. Sonin [12] have noted that 'resource curse' poses negative impact of economic structure on economic growth rate (not on the level of economic development). 'Resource curse' indicates the negative impact of the fact that natural resources dominate in a country's economy, not on the fact that they do exist.

According to M. Ross [16], in most developing countries there is a positive correlation between natural resources abundance and income inequal- 
ity. Income distribution and inequality issues, as well as quality of economic and political institutions, country's commitment to export, macroeconomic stability and human capital accumulation can be named among critical determinants of economic advance duration and stability in oil-exporting countries.

The relationship between income distribution and economic advance was studied by Galor and Zeira [8], Alesina and Rodrik [1], Persson and Tabellini [14] in 1994. The main conclusion of their theoretical and empirical researches was that inequality has a negative correlation with the economic advance in countries under research. T. Gylfason and G. Zoega [11] have demonstrated that investments into education in resources-rich countries can help to avoid economic advance rate reduction and inequality increase.

Above-mentioned mechanisms of 'resource curse' impact on resources-rich economic advance show the phenomenon of the 'Dutch disease' which means that the structure of resource-dependent countries becomes more oriented towards extracting and service sectors, where knowledge and human capital are not as highly-sought as they are in the industrial one. These spheres product is less positive technological externalities, which leads to technical growth deceleration and economic advance rate reduction. N. Volchkova [26] and E. Suslova studied the mechanism of 'resource curse' spread in the economy from the human capital accumulation point of view. They have discovered that one of the negative impacts of resource abundance on economic advance is that the motivation to invest into high human capital potential development is lower in a resources-dependent open economy than in the one poor in resources, due to the fact that labor is substituted by capital. Many research papers dedicated to 'resource curse' demonstrate that the growth of export-oriented extractive sector should be contained in a way so that it would not impair other economic sectors, especially the industrial one, as it will prevent the country from human capital outflow from high-technological creative areas.

V. Polterovich, V. Popov and A. Tonis [15] have studied different mechanisms of how resources abundance impact economic growth and have proven that resource availability aggravates free market shortcomings. Based on institutions and public administration quality, resource rent can either decelerate or accelerate the economic advance. These authors believe that resources-rich countries face a fundamental contradiction: market inconsistency requires state interference while low institutions' quality leads to interference inefficiency, which in turn implies bribery, backstairs influence, investments into resource rent "carve-up", not into production. Weak institutions hinder the country from effective administration of resource production revenues and pursuing the reasonable macroeconomic policy targeted at living standards enhancements and inequality decrease. Special attention should be paid to forms of inequality arising from changes in oil-producing countries' economies. Interest incomes in developing countries with weak institutions can lead to inequalities of different kinds:

- global inequality (such countries as Qatar, Kuwait, Brunei, etc. receive enormous revenues from oil export, have small populations and can boast highest per capita incomes);

- vertical inequality (when small groups of people control resource rent and receive the majority of revenue);

- horizontal inequality (when resources-rich regions within a country receive the majority of the revenue and develop, while those having no access to resource rent get behind);

- gender inequality (there are some data on gender inequality related to horizontal one);

- inequality between urban and rural households (in many developing countries resource rent is concentrated in the capital, while remote areas receive nothing).

Oil export indicators can serve as a basis for studying the influence of resources export revenues on living standards and inequality dynamics. We believe the most meaningful resources export indicators are the following:

- share of fuel resources export revenue in a country's GDP;

- share of fuel export in the whole export of goods in a country;

- oil export per capita;

- average per capita internal consumption of oil.

These indicators can define how the country is much dependent on oil and gas export. Let us have a closer look at some of them. The share of oil and gas export in the export of goods is high in most oil-producing countries bearing considerable raw material deposits. The connection between the share of oil and gas export in GDP and the share of oil and gas export in the export of goods throughout 2007-2011 is shown at picture 2 for 47 major oil-producing countries. It can be described by an exponential function with quite a high determination coefficient $\mathrm{R} 2=0,75$, which means that the level of dependency is high. This dependency shows that the majority of significant raw materi- 


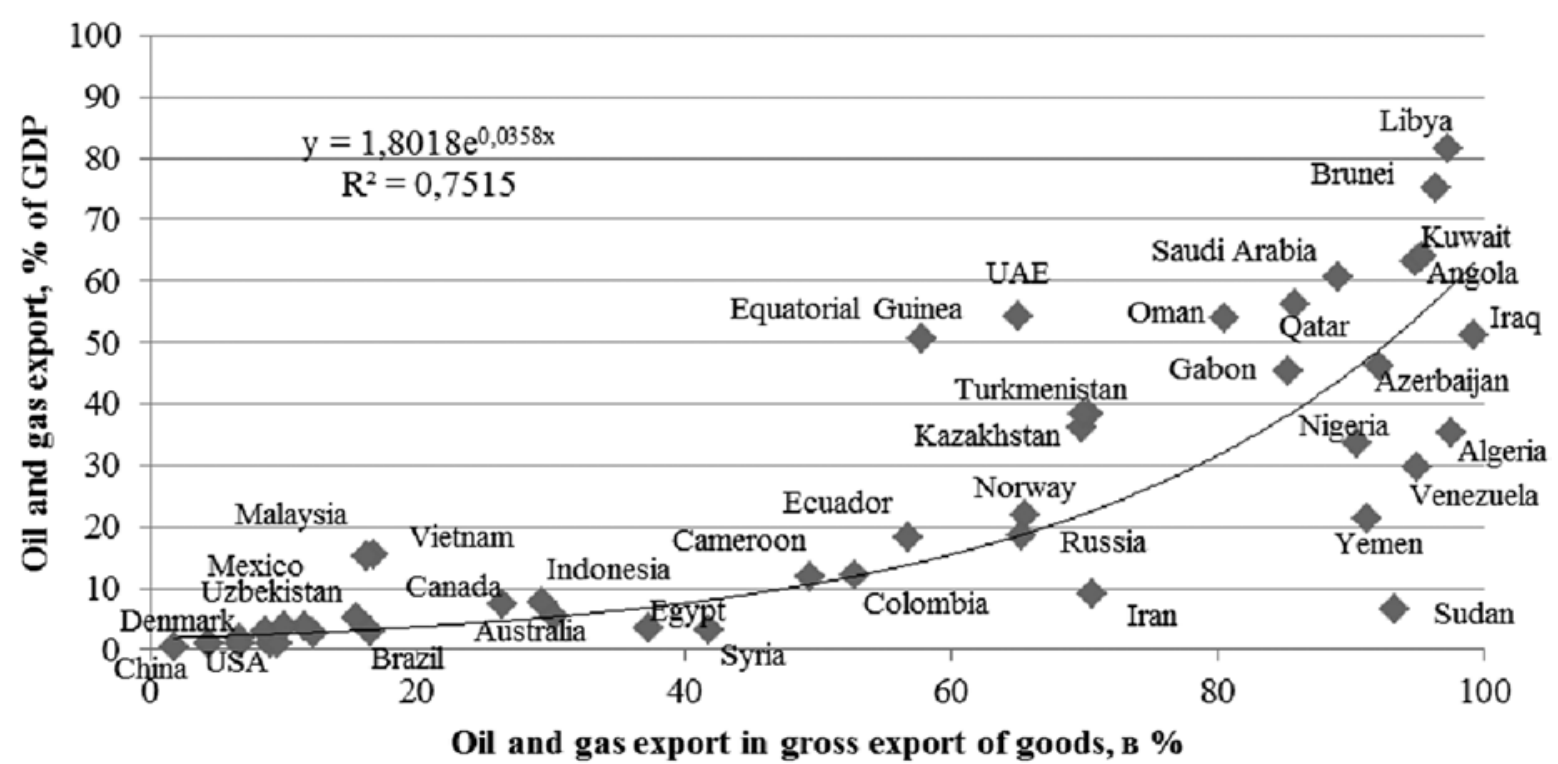

Pic. 2. Dependency between oil and gas export ratio in country's GDP and share of oil and gas export in total export of goods (based on information about 47 major oil-producing countries of the world). Source: composed by the author based on data [21, 5]: Statistical database of the World Bank. Available at: http://data.worldbank.org/indicator/, CIA World Factbook. 2011. Available at: http://www.eia.gov/countries/

als' exporting countries GDP is defined by oil and gas export.

Gross domestic product (GDP) is normally used as an indicator of economic prosperity and living standards within a country. However, it focuses on market production of goods and services and can lead to incorrect conclusions on population's incomes. Taking into account the process of globalization, the difference between the population's incomes and production revenues within a country (GDP) can be significant. That is because revenues generated in a country can be partially moved abroad, for example, when revenue is paid to foreign investors; in this case, it has absolutely no impact on a country's prosperity and does not increase people's purchasing power. Based on the Gross national income (GNI) at purchasing power parity per capita it is possible to conduct a more precise comparison of average per capita incomes between different countries, as long as this indicator demonstrates whether living standards get better. Certainly, there is even more precise indicator describing citizens' welfare, that is, the total disposable income of lower $80 \%$ or lower $50 \%$ of the population. Leading economists suggested using it [22] as an alternative to GDP. However, data on this indicator are not available for cross-country comparison, so let us think of how to eliminate drawbacks of GDP measurement.

There are several indicators that really measure citizens' welfare and can somehow neutralize the drawbacks of GDP. To determine whether citizens of the country earn more on their own or foreigners get higher incomes because of the coun- try's economic advance, such indicators as 'rate of money outflow from the country' and 'income drain'[17]. Rate of money outflow implies the ratio between GNI and GDP; in those countries where this coefficient is higher than 1, citizens gain advantages while smaller coefficient means that part of the country's revenue belongs to foreigners. 'Income drain' indicator can be estimated as a difference between GNI and GDP denominated in currency units.

Inequality and its measurement are an inevitable part of the living standards estimation. However, cross-country comparisons require relevant indicators. Such macroeconomic welfare indicators as GDP and GNI do not reflect whether revenue is distributed evenly between country's citizens, in other words, it does not depict distribution inequality. When considerable inequality changes happen, GDP as an aggregated indicator (even measured per capita) does not give a clear notion of the population's majority living standards. Taking into account the fact that income distribution inequality is high, average statistical indicators do not always show a real picture of citizens' and households' welfare, its group distribution, for example, interval indicators on consumption standards developed by All-Russian Center of Living Standards [3].

Table 1 contains main indicators of production output, oil export, economic advance rate, poverty and inequality indicators for 30 major oil-exporting countries, the export receipts of which are influenced greatly by interest incomes, that is, they constitute more than $20 \%$ of export of goods. 
World's major oil-exporting countries

\begin{tabular}{|c|c|c|c|c|c|c|c|c|c|}
\hline № & Country & $\begin{array}{l}\text { Extraction } \\
2012 \text { thou- } \\
\text { sand barr/ } \\
\text { day }\end{array}$ & $\begin{array}{l}\text { Export } \\
2009 \\
\text { thousand } \\
\text { barr/day }\end{array}$ & $\begin{array}{l}\text { GDP on } \\
\text { PPP per } \\
\text { capita }{ }^{*}, \text { US } \\
\text { Dollars, } \\
2012\end{array}$ & $\begin{array}{l}\text { Average } \\
\text { GDP } \\
\text { growth } \\
\text { rate, \% } \\
\text { 2001-2012 }\end{array}$ & $\begin{array}{l}\text { 'Income drain } \\
\text { from the } \\
\text { country', US } \\
\text { Dollars on } \\
\text { PPP per capita }\end{array}$ & $\begin{array}{l}\text { Rate of } \\
\text { money } \\
\text { outflow } \\
\text { from the } \\
\text { country }\end{array}$ & $\begin{array}{c}\text { Poverty } \\
\text { rate (na- } \\
\text { tional pov- } \\
\text { erty line), } \\
\% \text {, years. }\end{array}$ & $\begin{array}{c}\text { Inequality } \\
\text { rate (Gini } \\
\text { coefficient) }\end{array}$ \\
\hline 1 & Algeria & 1667 & 1694 & 8515 & 3.6 & -720 & 0.91 & $23.0(2006)$ & 35.3 (1995) \\
\hline 2 & Angola & 1784 & 1851 & 6105 & 10.3 & -615 & 0.90 & $40.5(2006)$ & $42.66(2006)$ \\
\hline 3 & Azerbaijan & 872 & 651 & 10624 & 13.2 & -1214 & 0.89 & $7.6(2011)$ & $34.0(2008)$ \\
\hline 4 & Brunei & 158 & 153 & 53348 & 1.5 & 237 & 1.00 & - & - \\
\hline 5 & Venezuela & 2725 & 1871 & 13475 & 3.7 & -355 & 0.97 & $25.4(2012)$ & $44.8(2006)$ \\
\hline 6 & Gabon & 245 & 213 & 16086 & 2.8 & -1796 & 0.89 & $32.7(2005)$ & $41.5(2005)$ \\
\hline 7 & Indonesia & 918 & 404 & 4956 & 5.4 & -146 & 0.97 & $12.0(2012)$ & $38.1(2011)$ \\
\hline 8 & Irag & 3115 & 1910 & 4246 & 2.3 & 54 & 1.01 & $22.9(2007)$ & 30.9 (2007) \\
\hline 9 & Iran & 3680 & 2523 & $11395^{*}$ & 5.1 & -1075 & 0.91 & - & $38.3(2005)$ \\
\hline 10 & Kazakhstan & 1728 & 1501 & 13892 & 8.0 & -1942 & 0.86 & $5.3(2012)$ & $29.04(2009)$ \\
\hline 11 & Cameroon & 653 & 101 & 2342 & 3.5 & -22 & 0.99 & $39.9(2007)$ & 38.91 (2007) \\
\hline 12 & Canada & 3741 & 1929 & 42693 & 1.9 & -3 & 1.00 & - & $32.6(2000)$ \\
\hline 13 & Qatar & 1966 & 1038 & $86506^{*}$ & 13.1 & -1836 & 0.98 & - & $41.1(2007)$ \\
\hline 14 & Colombia & 944 & 400 & 10587 & 4.3 & -477 & 0.95 & $34.1(2011)$ & $55.91(2010)$ \\
\hline 15 & Congo DR & 296 & 211 & 422 & 5.3 & -52 & 0.88 & $71.3(2005)$ & $44.43(2006)$ \\
\hline 16 & Kuwait & 3127 & 2127 & $49001^{*}$ & 5.7 & 2909 & 1.06 & - & - \\
\hline 17 & Libya & 1509 & 1385 & 17665 & 4.4 & -105 & 0.99 & - & - \\
\hline 18 & Malaysia & 657 & 0644 & 17143 & 4.7 & -613 & 0.96 & $3.8(2009)$ & 46.21 (2009) \\
\hline 19 & Mexico & 2911 & 1511 & 16676 & 2.2 & -46 & 1.00 & $51.3(2010)$ & $47.16(2010)$ \\
\hline 20 & Nigeria & 2417 & 2102 & 2661 & 6.5 & -241 & 0.91 & $62.6(2010)$ & $39.74(2011)$ \\
\hline 21 & Norway & 1916 & 2184 & 62767 & 1.6 & 1263 & 1.02 & - & $25.8(2000)$ \\
\hline 22 & UAE & 3380 & 2395 & 42384 & 4.4 & -3 & 1.00 & - & - \\
\hline 23 & Oman & 922 & 592 & 27015 & 4.9 & -1479 & 0.95 & - & - \\
\hline 24 & Russia & 10643 & 7301 & 23549 & 4.8 & -789 & 0.97 & & $40.11(2009)$ \\
\hline 25 & $\begin{array}{l}\text { Saudi } \\
\text { Arabia }\end{array}$ & 11530 & 7635 & $24571^{*}$ & 3.6 & 439 & 1.02 & - & - \\
\hline 26 & Sudan & 82 & 383 & 2195 & 4.0 & -165 & 0.92 & 46.5 (2009) & 35.29 (2009) \\
\hline 27 & $\begin{array}{l}\text { Trinidad } \\
\text { and Tobago }\end{array}$ & 121 & 242 & 26647 & 4.7 & -4247 & 0.84 & $17.0(2007)$ & $40.3(1992)$ \\
\hline 28 & Chad & 101 & 115 & 1493 & 8.7 & -173 & 0.88 & $55(2003)$ & $39.78(2003)$ \\
\hline 29 & Ecuador & 505 & 364 & 9738 & 4.4 & -148 & 0.98 & $27.3(2012)$ & $49.3(2010)$ \\
\hline 30 & $\begin{array}{l}\text { Equatorial } \\
\text { Guinea }\end{array}$ & 283 & 395 & 30233 & 14.5 & -11353 & 0.62 & $76,8(2006)$ & - \\
\hline
\end{tabular}

Source: composed by the author based on sources $[20,21,5]$

Notes: 1- Income drain is estimated as a difference between GNI and GDP in PPP (US Dollars) per capita for the year under investigation.

2 - Rate of money outflow is a ratio between GNI and GDP

3 - Poverty rate is estimated based on national poverty rate

GDP per capita in current US Dollars.

* data of year 2011, for Libya - year 2009.

Based on average per capita indicators, oil-producing countries can be conditionally subdivided into following groups:

1. Leaders (Norway, UAE, Kuwait, Qatar) where average per capita GDP (in PPP) constitutes not less than 35 thousand US dollars while the aver- age per capita extraction volume exceeds 50 tons. Canada and Brunei provisionally refer to this group, too.

2. Successful countries (Saudi Arabia, Russia, Oman, Trinidad and Tobago, Equatorial Guinea) where the average per capita GDP is not less than 

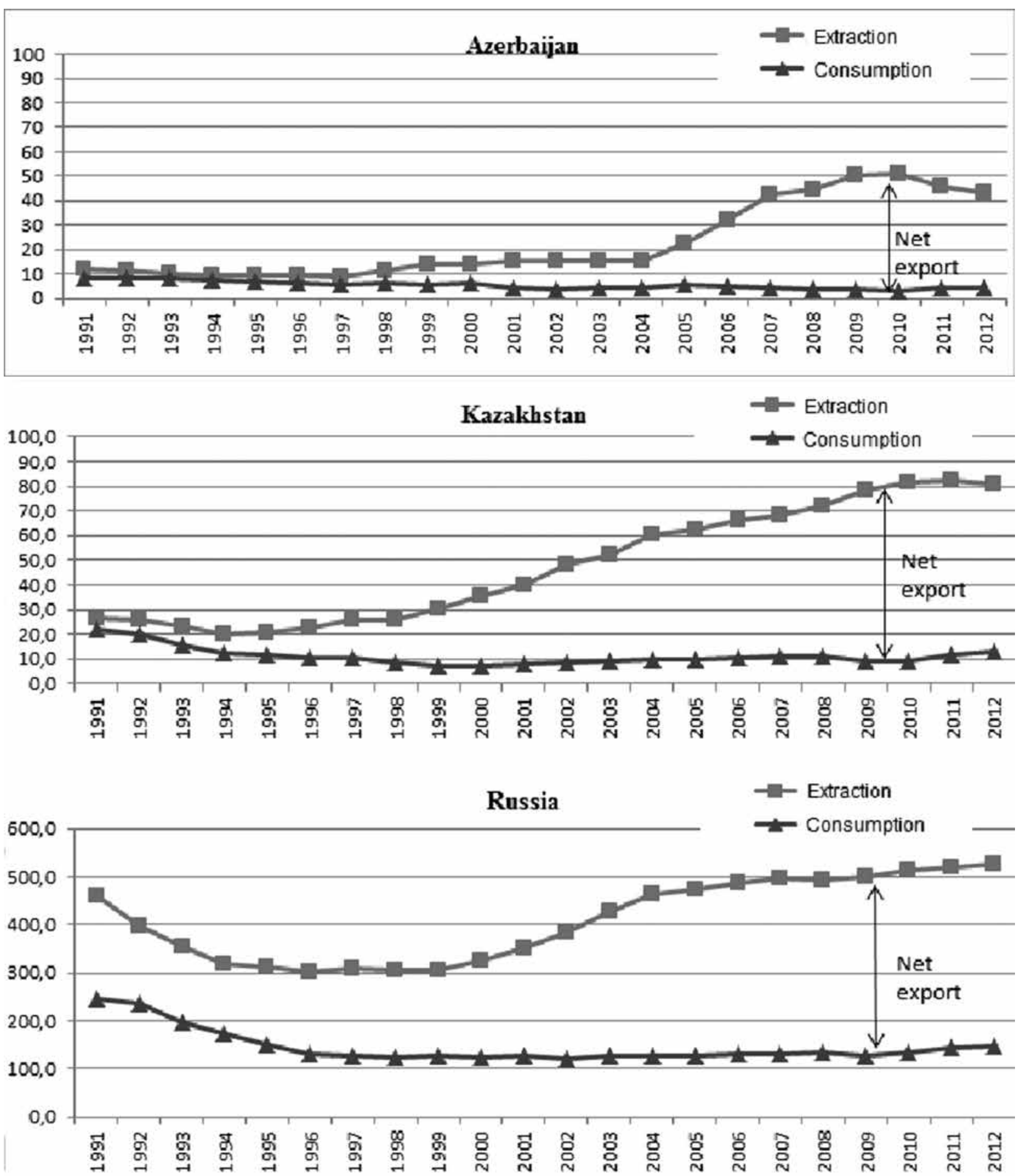

Pic. 3. Oil extraction and consumption in Azerbaijan, Kazakhstan and Russia in 1991-2012, millions of tons per year. Source: composed by the author based on [20] BP Statistical Review of World Energy June 2013. Available at: http://www.bp.com/ statisticalreview/

23 thousand US dollars while average per capita extraction volume varies between 15 and 30 tons;

3. Average countries (Venezuela, Algeria, Kazakhstan, Azerbaijan, Angora, Libya, Iran, Malaysia, Mexico) where average per capita GDP varies between 6 and 18 thousand US dollars while the average per capita extraction volume is between 5 and 10 tons;
4. Outsiders (Cameroon, Sudan, Nigeria, Indonesia) where the average income in PPP does not exceed 5 thousand US dollars while the average per capita extraction volume is less than 5 tons.

Data available on the table show that in most leading oil-exporting countries, there is income outflow, thus, population thereof does not receive 
all benefits of the resources export. Only some of these countries, such as Norway, Canada, Saudi Arabia, Kuwait, UAE, referring to leaders countries with successful economic policy where citizens' incomes grow faster than internal industry.

There are only three post-Soviet countries among major oil-exporters: Russia, Azerbaijan and Kazakhstan. After the collapse of the Soviet Union, all these three countries had similar conditions for further economic advance. First of all, state-planned economy was being transformed into a free-market one, leading to dramatic social, economic and political changes impacting all spheres of life in these countries. Secondly, before 1991 they did not participate in the system of international division of labor, meaning that their competitive situation among other oil-producers were disadvantageous. Thirdly, economies of Russia, Azerbaijan and Kazakhstan were still dependent on internal economic ties between post-Soviet countries. Reservoir engineering and export management require considerable production and infrastructure investments. As long as these countries did not have sufficient financial resources of their own in order to invest into oil and gas industry, they definitely required foreign funds for oil and gas industry development. Investment inflow puts the industry on a new level and led these countries into the group of major oil-exporting countries in the world.

Apart from positive changes, such as oil export revenue growth, there were some disadvantages, too. Big inflow of investments into the country led to increased dependence of economic advance on high impact of oil and gas industry. Among post-Soviet countries enumerated in Table 1 average GDP growth rate in 2001-2012 was the highest in Azerbaijan (13.2\%) and Kazakhstan. For these three countries, oil production has become the major influence on GDP contributing the majority of the state budget revenues. Shares of oil and gas revenues in the whole structure of export of goods for Azerbaijan and Kazakhstan are 95\% and $73 \%$ respectively (as of 2011) [21].

As we can see on Picture 3 , the volume of oil production 10.2 times exceeds the volume of oil consumption in Azerbaijan, 6.3 times for Kazakhstan and 3.6 times for Russia. Clearly, the country's economy should be capable of reworking natural resources effectively and only export some of the surpluses thereof. But, it is only true when processing industries bear effective high-technology processes. For example, such countries as China, the USA and the Netherlands are both raw materials importers and exporters: they import oil, they do high-refinery works, and products thereof are exported taking into account added value. However, it is typical of post-Soviet countries to actively develop oil production while maintaining the same level of internal consumption and processing since the beginning of 2000th (Pic. 3). Taking into account current economic policy, it is more profitable for post-Soviet countries to export oil rather than process it within the country, which means that these countries are dependent on resources export.

After the breakup of the Soviet Union, those export-oriented economies that experienced dramatic growth and development and oil production industry turned into the resource-dependent countries. Their economic problems are caused by the fact that raw materials dominate in their national operations and their inability to manage such revenues effectively. If the financial influx based on growing raw material export revenues is administered via the primary income distribution system and is spent mainly on consumption, not on manufacturing industry development, it means that oil revenues maintain economy's dependency on raw materials and alter its structure in a way that extraction industries will dominate [15]. According to an analytical report by BP, the majority of oil resources is consumed in developed countries [20], that is why resources-exporting countries are responsible for resources export revenues re-investment.

Dependency on raw materials modifies the structure of the economy because such industries as trade; construction, brokering services, financial services and real estate become main recipients of hydrocarbons export interest incomes. At the same time, other spheres suffer from lesser potential for development. According to the GDP structure analysis using a system of national accounts, changes in the structure of these three countries' economies harm agriculture and processing industries (mainly food processing and consumer goods industry) that become less attractive for potential investors and employees (Pic. 4). Apart from that, oil revenues spur active development of such realms as financial services, real estate operations, and trade, that is, those industries that are tightly connected to the financial industry and are more prone to the financial crisis.

Differences between potential salaries in different spheres of the economy also influence the employment patterns: depending on its mobility, workforce bypasses into sectors with higher salaries. It entails inequality based on job incomes. Moreover, highly qualified staff takes on jobs in industries with higher salaries, that is, extraction industries, which makes the latter more competitive 


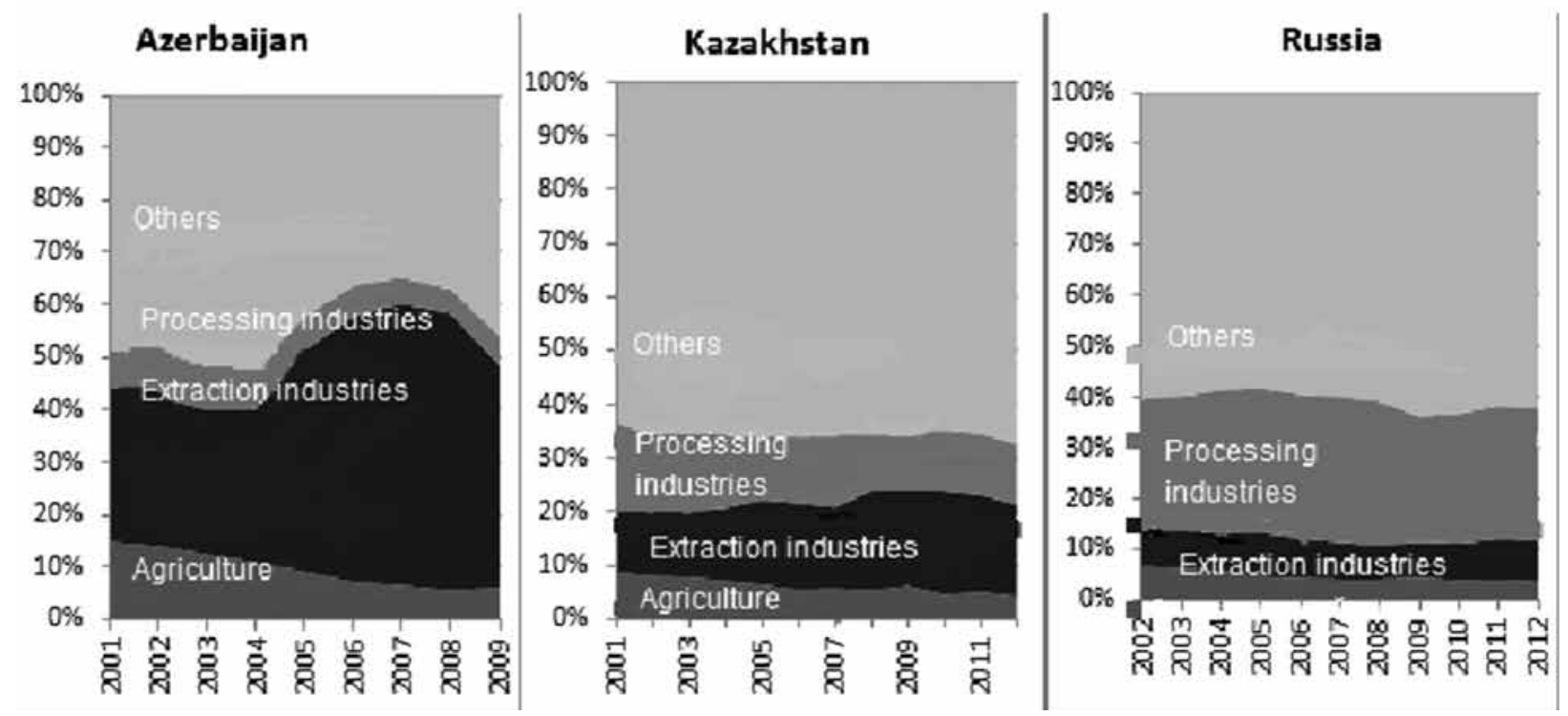

Pic. 4. Economic structures of Azerbaijan, Kazakhstan and Russia based on the SNA, \%. Source: compose by the author based on the System of National Accounts data [7, 24, 25]. Notes: GDP structure consists of four spheres: agriculture, extraction industry, processing industry and others (including electric power, gas and water production and distribution, construction, as well as all types of services). Since 2002 economies of Azerbaijan, Kazakhstan and Russia have been showing a clear tendency of agriculture and processing industry contraction and growth of extraction industry and services

in comparison with other sectors. As a result, the potentiality of the economy sectors alters in favor of capital-intensive export-oriented industries.

Unfortunately, country's economic advance and resources export revenues growth do not always entail increase in citizens' living standards and quality of living that are greatly influenced by primary revenue distribution and re-distribution systems, the latter being determined by the governmental social and economic policy. Table 2 outlines major indicators of dependency between oil export, welfare and income inequality for three countries: Azerbaijan, Kazakhstan and Russia.
Clearly, any cross-country inequality comparison, including Gini coefficient, should only interpret such indicators taking into account country's economic advance and structure of its economy, as well as information on income distribution because inequality indicators themselves do not bear any considerable meaning. A country can be poor, but wealth divide can be not that significant, as long as almost all the population is equally poor. However, if national income in PPP per capita is high, even a comparatively low Gini coefficient can mean that income divide can be higher than in a country with

Statistical data on welfare, inequality and dependency on export for three countries

\begin{tabular}{|c|c|c|c|}
\hline Indicators & Azerbaijan & Kazakhstan & Russia \\
\hline GNI per capita in PPP, US Dollars, year 2012 & 9410 & 11950 & 22760 \\
\hline Oil extraction, tons per capita, year 2012 & 4.73 & 4.91 & 3.68 \\
\hline Internal consumption, tons per capita, year 2012 & 0.46 & 0.77 & 1.03 \\
\hline Share of oil and gas export in country's GDP, \% & 46.3 & 36.0 & 18.7 \\
\hline Share of oil export in gross export ${ }^{\star}, \%$ (average for years 2007-2011) & 92.1 & 69.8 & 65.3 \\
\hline Rate of money outflow (GNI/GDP ratio), average for years 2007-2012 & 0.89 & 0.87 & 0.97 \\
\hline Gini index, year 2009 & 34.0 & 29.04 & 40.11 \\
\hline Income share of $10 \%$ of the population with lowest incomes, year 2009 & 3.43 & 4.00 & 2.75 \\
\hline Income share of $10 \%$ of the population with highest incomes, year 2009 & 27.37 & 23.80 & 31.68 \\
\hline
\end{tabular}

Source: composed by the author based on data $[20,21]$ from the Statistical database of the World Bank [Electronic source] / Access mode: http://data.worldbank.org/indicator/.

* author's calculations are based on data $[20,21]$.

Nore: in Azerbaijan and Russia Gini index is calculated based on the population's cash income, while in Kazakhstan it is estimated based on the consumption level. Gini index demonstrating inequality in terms of consumption is a little bit lower than cash income inequality, based on what we can assume that cash income inequality in Kazakhstan is not lower than the one in Azerbaijan or Russia. 
the same Gini coefficient and lower national income per capita.

Per capita indicators of oil extraction and internal consumption demonstrate that at present Russia is a little bit less dependent on oil export than Kazakhstan and Azerbaijan. However, GNI per capita, Gini index and income share of $10 \%$ of the population with the highest incomes show that inequality in Russia is the highest among these three countries (Table 2). Thus, statistical data confirm the inequality in the oil export benefits distribution stipulated by the income distribution system existing in post-Soviet oil-producing countries.

Inequality in resources export income distribution gives rise to several problems in oil-producing regions, including growth in labor migration, poverty, income inequality, labor conflicts. That is why governments of Azerbaijan, Kazakhstan and Russia face the challenge of administering oil and other raw material sales revenues effectively in order to facilitate stable economic advance, living standards increase and inequality decline.

Let us enumerate some directions of state influence. Foreign researches and experience of other countries rich in natural resources show that economic advance rate decrease and inequality growth can be prevented by investments into professional education and human potential. Workforce skill set development is one of the main ways to address inequality growth effects [13]. Employment policy of any country should be targeted at both employment boosting and professional development.

Post-Soviet oil-producing countries should also reasonably administer stabilization (reserve) National Foundation accumulating raw material export revenues. However, it is even more impor- tant to take into account the influence of labor compensation and employment policy, social insurance system, economy diversification targeted at technology enhancement and implementation into agriculture on income distribution. Such countries as Canada, Australia, Norway, Malaysia, Indonesia, UAE, etc. show great examples of how natural resources can be effectively used for comprehensive economic advance, containment of dependency from resource rent and facilitating high standard of living for the population of countries exporting raw materials.

\section{Conclusion}

Raw materials availability within a country offers it great opportunities for receiving high export incomes, which in turn can have a favorable effect on social and economic development. On the other hand, oil export revenues can have a negative impact on the structure of country's economy, as long as extraction industries will develop better at the expense of agriculture and processing industries.

Estimation of dependency on oil export using statistical indicators shows that influx of resources sales revenue into post-Soviet countries aggravates their export dependency. Oil export incomes have influenced the GDP growth, however, they have also stipulated conditions for population welfare divide and inequality expansion in Russia, Kazakhstan, and Azerbaijan.

Post-Soviet countries rich in natural resources are to diversify the structure of their economies in order to decrease dependency on resource rent and increase the share of processing industry products, innovations and services in gross national income, as well as enhance the mechanisms of investments into economy.

\section{References}

1. Alesina A., Rodrik D. (1994). Distributive politics and economic growth. Quarterly Journal of Economic,109 (2): 465-490.

2. Auty R. (2001). Resource Abundance and Economic Development. Oxford, OUP. 2.

3. Bobkob V.N. (2012). 20 let kapitalisticheskikh transformatsiy v Rossii: vliyanie na uroven I kachestvo zhizni [20 years of capitalist transformations in Russia: influence on quality and standards of living]. Mir Rossii [Universe of Russia], 2.

4. Brunnshweiller C. N. (2006). Cursing the Blessing? Natural Resource Abundance, Institutions and Economic Growth. ETH Economic Working Papers, 51.

5. CIA World Factbook. (2011). Available at: http://www.eia.gov/countries/.

6. Corden W.M. (1984). Booming Sector and Dutch Disease Economics: Survey and Consolidation. Oxford Economic Papers, 36.

7. Sbornik natsionalnyye scheta Rossii v 2005-2012 [Digest 'National Accounts of Russia in 2005-2012']. Available at: http:// www.gks.ru/wps/wcm/connect/rosstat_main/rosstat/ru/statistics/publications/catalog/doc_1135087050375http://www.gks.ru/ wps/wcm/connect/rosstat_main/rosstat/ru/statistics/publications/catalog/doc_1135087050375.

8. Galor O., Zeira J. (1993). Income Distribution and Macroeconomics. The Review of Economic Studies, Vol. 60, 1, 35-52.

9. Gelb A. (1988). Oil Windfalls: Blessing or Curse? N.Y.: World Bank Research Publications.

10. Guriev S., Sonin K. (2008). Ekonomika "resursnogo proklyatiya" [Economy of 'resource curse']. Voprosy ekonomiki [Economy issues], 4, 1-14.

11. Gylfason T. G., Zoega G. (2002). Inequality and Economic Growth: Do Natural Resources Matter? CESifo Working Papers Series, 712 
12. Hartwick J. (1990). Natural Resources, National Accounting and Economic Depreciation. Journal of Public Economics. Vol. 43, 291-304.

13. OECD. 2011. Divided We Stand: Why Inequality Keeps Rising? Available at: http://www.oecd.org/els/soc/dividedwestandwhyinequalitykeepsrising.htm.

14. Persson T., Tabellini G. (1994). Is Inequality Harmful for Growth? The American Economic Review, Vol. 84, 3, 600-621.

15. Polterovich V., Popov V., Tonis A. (2007). Mekhanizmy "resursnogo proklyatiya" i ekonomicheskaya politika ['Resource curse' mechanisms and economic policy]. Voprosy ekonomiki [Economy issues], 6.

16. Ross M.L. (2007). How Mineral-Rich States Can Reduce Inequality. Escaping the Resource Curse, Columbia University Press.

17. Sabyrova L. (2009). VVP i VND: otsenka ottoka natsionalnogo dokhoda [GDP and GNI: national revenue outflow estimation]. Kazakhskiy ekonomicheskiy vestnik [Kazakh economic reporter], 1, 106-109.

18. Sachs J., Warner A. (1995). Natural Resource Abundance and Economic Growth. NBER Working Papers №W5398.

19. Sala-i-Martin X. (1997). I Just Run Two Million Regressions. American Economic Review Papers and Proceedings. Vol. 87, $1,178-183$.

20. Statistical Review of World Energy 2013. Available at: http://www.bp.com/en/global/corporate/about-bp/statistical-review-of-world-energy-2013.html.

21. Statisticheskaya baza dannykh vsemirnogo banka [Statistical database of the World Bank]. Available at: http://data.worldbank.org/indicator/.

22. Stiglitz J.E., Sen A., Fitoussi J-P. Report by the Commission on the Measurement of Economic Performance and Social Progress. Available at: http://www.stiglitz-sen-fitoussi.fr/documents/rapport_anglais.pdfhttp://www.stiglitz-sen-fitoussi.fr/documents/rapport_anglais.pdf.

23. Syrlybaeva B. (2009). Sopostavitelnyy analiz i tsenka struktury eksporta Kazakhstana [Comparative analysis and estimation of export structure in Kazakhstan]. Kazakhskiy ekonomicheskiy vestnik [Kazakh economic reporter], 2-3, 67-79.

24. Sistema natsinalnykh schetov Aizerbadzhana. Sayt Goskomstata Aizerbadzhana [System of national accounts of Azerbaijan. State statistics service of Azerbaijan website]. Available at: http://www.stat.gov.az/source/system_nat_accounts/indexen.php.

25. Sistema natsinalnykh schetov Respubliki Kazakhstan. Ofitsialnyy sayt agentstva RK po statistike [System of national accounts in Republic of Kazakhstan. Official website of statistics agency for Republic of Kazakhstan]. Available at: http://www.stat.kz/ vs_scheta/int_scheta/Pages/default.aspx.

26. Volchkova N., Suslova E. (2008). Chelovecheskiy kapital, promyshlennyy rost i resursnoye proklyatie [Human capital, industrial growth and resource curse]. Ekonomicheskiy zhurnal VShE [Economic journal of Higher school of Economy], 2.

\section{Information about the author}

Aliev Ulvi Takhir ogly (Baku, Azerbaidzhan) - PhD in Physical and Mathematical Sciences, the Head of Caspian Quality of Life Center (17, K. Ragimova st., Baku, AZ-1072, Azerbaidzhan e-mail: ulvi.aliyev1963@gmail.com). 